\title{
Microbiological evaluation of sachet water and street-vended yoghurt and “Zobo" drinks sold in Nsukka metropolis
}

\author{
I.E. MBAEYI-NWAOHA* and N.I. EGBUCHE \\ Department of Food Science and Technology, University of Nigeria, Nsukka. \\ *Corresponding author: miphie2003@yahoo.co.uk or ifeoma.mbaeyi-nwaoha@unn.edu.ng
}

\begin{abstract}
Microbial, physical and chemical characteristics of six brands of sachet water and street-vended yoghurt (two) and "Zobo" drinks (three) sold in Nsukka metropolis were studied. Parameters such pH, total dissolved solids, copper, iron, alkalinity, appearance, taste, colour, aerobic mesophilic count, coliform counts were evaluated. Data obtained from the study showed that the yoghurt and "Zobo" drinks sold at the moment are bacteriologically safe. "Zobo" drink samples had total plate count of $9.9 \times 10^{1} \mathrm{CFU} / \mathrm{ml}$ to $1.48 \times 10^{2} \mathrm{CFU} / \mathrm{ml}$, negative to coliform, Salmonella, and E. coli. Yoghurt samples had total plate count of $9.9 \times 10^{1} \mathrm{CFU} / \mathrm{ml}$ to $1.59 \times 10^{2} \mathrm{CFU} / \mathrm{ml}$, negative to coliform, Salmonella and E. coli. Sachet water samples had pH of 7.25 to 7.50 , total dissolved solids of $2.66 \mathrm{ppm}$ to $15.03 \mathrm{ppm}$, hardness of $0.24 \mathrm{ppm}$ to $15.00 \mathrm{ppm}$, iron, nitrate and nitrite were not detected. A total plate count of $1.41 \times 10^{2}$ to $3.19 \times 10^{2}$, negative to Salmonella spp and some positive to Pseudomonas spp, coliform and E. coli. Thus the need for improved water treatment methods and storage before drinking and use for food drink processing.

(C) 2012 International Formulae Group. All rights reserved.
\end{abstract}

Keywords: Aerobic mesophilic count, Coliforms, Street-vended, Water, Yoghurt, “Zobo’”.

\section{INTRODUCTION}

Water is a chemical substance that is composed of hydrogen and oxygen. It is vital for all known forms of life and the most abundant natural essential commodity since it covers $71 \%$ of the earth's surface. However, clean drinking water is essential to humans and other forms of life. Water fit for human consumption is called potable water or drinking water. To function properly, the body requires between one to seven (1-7) litres of water per day to avoid dehydration (Ajayi, 2005). This depends on the level of acidity, temperature, humidity, and amount of alcohol and caffeine intake (Campbell et al., 2006).
Most of this is ingested through foods or beverages such as fruit juices, ice crème, and yoghurt among others, other than drinking water alone. Humans require safe water that contains little or no impurities. Common impurities include metals salts and oxides (including copper, iron, calcium and lead) and/or harmful bacteria such as Vibrio cholera, E. coli, Salmonella, Pseudomonas spp among others.

Water naturally occurs as marine, fresh estuarine, underground and rainwater but these natural sources of water are becoming scarcer in certain places and its availability is a major social and economic concern. Various 
water supply schemes are being adapted to help alleviate the problem of good quality water supply. The conventional water schemes employed boreholes, hand dung wells, surface water such as streams, rivers, lakes, oceans and rain harvesting (Brennam et al., 1975; Morgan, 1990). To maintain quality control, there must be adequate information on the nature and capacity of natural source of water, their hydrology and geology, but most importantly their physical, chemical and biological quality.

However, potable water systems can become polluted with coliforms and pathogenic bacteria from normal, diseased or carrier human and animal excrement (Pelezar et al., 1986). Therefore an adequate supply of clean, wholesome water for domestic consumption must be carefully treated before use so that it is not injurious to health (Egwari and Aboaba, 2002; United States Centers for Disease Control and Prevention, 2006). One means of establishing and assuring the purity and safety of water is to set a standard for various contaminants. The quality of water is usually judged by the degree to which it conforms to physical, chemical and biological internationally/nationally accepted standard set by regulatory bodies or organizations such as the World Health Organization (WHO, 2006) and the National Agency for Food and Drug Administration and Control (NAFDAC) as reported by Oyebode (2005).

Meanwhile, water is replenished by taking yoghurt (Kolars et al., 1984; National Yoghurt Association, 2007), ice crème or drinking liquids like fruit drinks and beverages(Anne, 2002; Qi et al., 2005). Various types of drinks/beverages are often consumed as source of fluids (Dada, 2009a,b). Fruit drinks are directly extracted from fruits and consumed with further processing (Aliyu, 2000; Fasejiro et al., 2005). Some of these are packaged in bottles or laminate papers and sold (Ogan, 1992: Kassenga, 2007). Fruits have been a part of human diet and food supplement over the years. According to
Wenkam (1990); Okwu and Emenike (2006), fruit drinks are considered as healthy food supplements because they contain high quality water, carbohydrates, proteins, vitamins $\mathrm{A}, \mathrm{B}_{1}$, $\mathrm{B}_{2}, \mathrm{C}, \mathrm{D}$ and $\mathrm{E}$ as well as calcium (Ca), magnesium $(\mathrm{Mg})$, potassium $(\mathrm{K})$, zinc $(\mathrm{Zn})$, and iron $(\mathrm{Fe})$.

The quest for cheap and readily available source of potable water has led to the emergence of sachet water popularly known as 'pure water' (Dibua et al., 2007). With the significance increase in sachet and bottled water consumption, there has risen a growing concern on the microbial quality of these products. Sachet or bottled water like any other food product must be processed and packaged aseptically. Sachet water generally is not produced sterile. Contaminants are introduced by the source and storage facility of the water supply. They can also be introduced during manufacturing and consumer handling (Warburton and Austin, 1997). Irrespective of their sources, these products are susceptible to microbial contamination with deleterious public health.

Similarly, the simplicity of producing fruit juices and yoghurt, availability of raw materials and abject poverty in many rural communities as well as the new economy revamp policies of the government have resulted in increased production and consumption of many locally made fruit drinks and yoghurt at cottage levels in Nigeria (Awolola et al., 2009). In spite of the high consumption rate of these beverages, their microbial qualities are not well documented. During harmattan/dry season, people get dehydrated easily and often. In the bid of compensating for the lost of water through sweating and urination, they take sachet water, ice crème, yoghurt (Salina, 1982; Okpalaugo et al., 2008) and/or fruit drinks such as "Zobo" (mostly consumed by school children) as a source of refreshment and rehydration. Also, with the malfunctioning or rather "close down" of Water Board Cooperation in Nigeria, treated pipe borne 
water has become a thing of the past. People now depend solely on boreholes, wells, streams and water suppliers in tankers whom their sources of water are still unknown.

According to research conducted by Coker (2004), 70\% of people living in Lagos derive their water supply from other sources other than the state municipals, many people depend on water vendors whom they pay heavily for provision of water to meet their daily needs.

Consequently, water from any of these sources is used in the production of these products (sachet water, zobo drinks and yoghurt) with doubt of further purification. Hence the microbial quality, method of preparation and source of raw materials for these products become very questionable as people after consumption fall sick.

In view of the threat posed by the bacterial pathogens in commercial yoghurt, zobo drinks and sachet water, and in addition to the flourishing demand for such street vended products, the main aim of this work is to evaluate the quality of sachet water as well as zobo and yoghurt sold in Nsukka metropolis. The specific objectives of this work were to assess the microbiological quality of sachet water, yoghurt and zobo drinks as well as to compare the result obtained with standard set by WHO and NAFDAC for these products.

\section{MATERIALS AND METHODS Collection of samples Sachet water}

To ensure adequate representation sampling a preliminary survey was conducted before selection of sachet water samples to be analyzed. Inquires were made randomly to identify popular brands names commonly patronized in Nsukka. Following this procedure six (6) brands of sachet water were identified. Three (3) samples for each identified brand collected at different locations accounted for the 18 water samples analyzed. Samples were purchased from different strategic selling points ranging from factory distributors stores and outdoor vendors as shown in Table 1 below. "Zobo" drinks consumed by most people were purchased at different selling points. Sampling was made from University of Nigeria Nsukka campus and Nsukka town.

\section{Sample preservation}

Purchased sachet water, yoghurt and zobo drink samples were carefully transported to the laboratory and kept in the refrigerator (4 ${ }^{\circ} \mathrm{C}$ ) and then used for analysis. Samples were analyzed within 48 hours of purchase.

\section{Physical examination}

Physical examination was aimed at detecting odour, taste and appearance of the sample.

Odour

Fifty millilitres $(50 \mathrm{ml})$ wide mouthed glass-stoppered bottles were rinsed with $4 \mathrm{M}$ hydrochloric acid $(\mathrm{HCl})$ until completely odourless and then re-rinsed with distilled water. The bottles were half-filled with each sample stoppered and shaken vigorously for 2-3 seconds. The stoppers were then removed and samples observed for odour by putting the nostril near the mouth of the bottle.

Taste

A clean sterile spatula was used to take aliquots of each sample and then tested with the tip of the tongue and the taste noted immediately.

\section{Appearance}

Samples were poured into clean greasefree beaker and viewed directly through the beaker with naked eyes to determine the colour of the sample and presence of particles.

\section{Chemical examination \\ Metal analysis}

Iron, lead and copper concentrations were analyzed in all sachet water samples using LaMotte smart spectrophotometer titration kit. 
Total dissolved solids, conductivity and $\mathrm{pH}$ determination

Electrical conductivity meter was used for the analysis of total dissolved solids and conductivity. $\mathrm{pH}$ was determined using $\mathrm{pH}$ meter as described by Saxena (1990).

Mineral determination and hardness

Chloride, sulphur, nitrate, nitrite, calcium and magnesium concentrations were analysed in all sachet water samples using LaMotte smart spectrophotometer titration kit.

\section{Carbon dioxide determination}

Carbon dioxide concentrations were analyzed in all sachet water samples using LaMotte smart spectrophotometer titration kit.

\section{Microbiological assessment Media preparation}

The media were prepared according to manufacturer's instructions. Unless otherwise stated all the media (Merck Company) were sterilized using Astell Scientific autoclave (Model: AACO46 England) at $121{ }^{\circ} \mathrm{C}$ for 15 minutes at 15psi gauze pressure. Broth culture media consisting of $9 \mathrm{ml}$ lauryl sulfate broth in McCartney bottles with inverted Durham tube were sterilized as stated above (same as Brilliant - green lactose bile broth). All glasswares including McCartney bottles conical flasks among others were sterilized in hot air oven (Binder model: FF400 Germany) at $60{ }^{\circ} \mathrm{C}$ for 2 hours. Prepared media were maintained at $45{ }^{\circ} \mathrm{C}$ in a water bath (Kottermann model: D-3165 Germany) before use.

\section{Enumeration of aerobic mesophilic bacteria (Plate count)}

Pour-plate inoculation method as described in APHA (1992) was adopted using sterile molten plate count agar medium. A set of appropriately labeled sterile disposable Petri-dishes were set out. Into each labeled plate one millilitres $(1 \mathrm{ml})$ from $10^{3}$ - sample dilution was dispensed. Approximately $15 \mathrm{ml}$ of freshly prepared plate count agar (PCA) medium was poured into each inoculated plate. Inoculated plates were rocked gently and allowed to solidify in the upright position. Inoculated plates were then incubated in an incubator (Gallenkamp model: 4H-150) in the reverse position at $37{ }^{\circ} \mathrm{C}$ for 48 hours. After incubation the mean count of bacterial colonies in duplicate plate was recorded and the result expressed as:-

$$
\mathrm{AMB}=\frac{\text { No. of colonies } \mathrm{X} \text { dilution factor }}{\text { Volume of sample plated. }}
$$

Where $\mathrm{AMB}=$ Aerobic Mesophilic Bacteria $\left(\alpha \times 10^{3}\right.$ $\mathrm{CFU} / \mathrm{ml}) ; \quad \alpha=$ number of colonies counted.

\section{Enumeration of coliform bacteria}

The standard Most Probable Number (MPN) method using 3-tube dilution as outlined in APHA (1992) was employed for the enumeration of coliform. Lauryl sulfate broth medium in McCartney bottles were set out in rows of three $(3 \mathrm{~s})$. Each tube was inoculated with $1 \mathrm{ml}$ of $10^{3}$-sample dilution. Inoculated tubes were incubated in an incubator (Gallenkamp model: $1 \mathrm{H}-150$ ) at 37 ${ }^{\circ} \mathrm{C}$ for 48 hours. Positive results were indicated by the production of 'acid and gas' (that is presence of gas in the inverted Durham tubes and change in colour of the medium from yellowish brown to milky colour). A loop from each gas positive tubes were transferred into separate tubes of brilliant-green lactose bile broth with Durham tubes and re-incubated at $37{ }^{\circ} \mathrm{C}$ for 48 hours. Gas production confirms the presence of coliform bacteria.

\section{Enumeration of Escherichia coli (E. coli)}

The pour-plate method was adopted using double layered violet red bile agar (VRBA) medium. Inoculated tubes were incubated in a Gallenkamp (Model: 1H-158) incubator at $44.5{ }^{\circ} \mathrm{C}$ for 48 hours. Pinkish spindle-shaped colonies of E. coli were purified and then confirmed after gram's staining and further biochemical tests.

\section{Enumeration of Salmonella}

The pour-plate method was employed. Samples were inoculated with Salmonella Shigella agar (SSA) and incubated in a 
Gallenkamp (Model $1 \mathrm{H}-150$ ) at $37{ }^{\circ} \mathrm{C}$ for 48 hours.

\section{Enumeration of Pseudomonas spp}

The pour-plate method was adopted using centimide agar (CA) medium. Inoculated plates were incubated at $37{ }^{\circ} \mathrm{C}$ for 48 hours in a Gallenkamp incubator (Model 1H- 150). Positive results were indicated by the change in medium colour from colourless to yellowish green colour.

\section{RESULTS AND DISCUSSION \\ Physical oganoleptic Examination of samples}

Table 2 below summaries the physical characteristics of the water samples used in the study. The physical/organoleptic parameters of water samples were in line with the standard set by WHO/NAFDAC "that water for drinking should be colourless, odourless, tasteless and free from particles". Odour is recognized as a quality factor affecting acceptability of drinking water and food prepared from it (such as zobo and yoghurt). Most organic and some inorganic chemicals contribute taste or odour. These chemicals may originate from municipal and industrial waste discharges, natural sources, such as decomposition of vegetable matter or from associated microbial activity. Colour in water may be due to the inorganic ions, such as iron and manganese, humus and peat materials, plankton, weeds and industrial wastes.

The absence of colour, taste, odour and particles in the samples can be attributed to Good Manufacturing Practice and the presence of particles in zobo 2 sample (as shown in Table 3 above) can be related to improper filtration of the leaves from the zobo drink prior to pasteurization.

\section{Metal analysis of water samples}

Anaerobic ground waters may contain iron II at concentrations up to several milligrams per liter without discoloration or turbidity in the water when directly pumped from a well. However, iron contents were not detected in any water samples. Taste is not usually noticeable at iron concentrations below $0.3 \mathrm{mg} / \mathrm{l}$, although turbidity and colour may develop in piped systems at levels above 0.05 to $0.1 \mathrm{mg} / \mathrm{l}$. Iron is an essential element in human nutrition but long time consumption of drinking water with a high concentration of iron can lead to liver diseases (hemosiderosis). The acceptable amount of iron in water as stipulated by NAFDAC is $0.03 \mathrm{mg} / \mathrm{l}$ maximum. Iron also promotes the growth of iron-bacteria. This gives a rusty appearance to the waters. Colonies of these bacteria may also form a slime which causes problems in water closets, pipes, pumps and distribution system.

Copper is found mainly as a sulphide, oxide, or carbonate in the minerals. Copper enters the water system through mineral dissolution, industrial effluents, because of its use as algicide and insecticide and through corrosion of copper alloy water distribution pipes. It may occur in simple ionic form or in one of many complexes with groups, such as cyanides, chlorides, ammonia or organic ligands. Desirable limit for copper in potable water as set by NAFDAC is $1.00 \mathrm{mg} / \mathrm{l}$ maximum. All water samples fell into standards and lead as well was not detected.

Total dissolved solids, conductivity and $\mathrm{pH}$ of water samples

Table 3 shows the total dissolved solids, conductivity and $\mathrm{pH}$ of the water samples. The total dissolved solids complied with the standards set by NAFDAC to be 500 $\mathrm{mg} / \mathrm{l}$ maximum for potable water. Many dissolved substances are undesirable in water. Dissolved minerals, gases and organic constituents may produce aesthetically displeasing colour, taste and odour, yet others have been identified as carcinogens. Water with higher solids content often has a laxative and sometimes the reverse effect upon people whose bodies are not adjusted to them.

Specific conductance yields a measure of water's capacity to convey an electric current. This property is related to the total 
concentration of the ionized substances in water and the temperature at which the measurement is made, the nature of the various dissolved substances, their actual and relative concentrations, and the ionic strength of the water sample vitally affects the specific conductance.

$\mathrm{pH}$ value is the logarithm of reciprocal of hydrogen ion activity in moles per liter. In water solution, variations in $\mathrm{pH}$ value from 7 are mainly due to hydrolysis of salts of strong bases and weak acids or vice versa. Dissolved gases such as carbon dioxide, hydrogen sulphide and ammonia also affect the $\mathrm{pH}$ of water. The overall $\mathrm{pH}$ range of natural water is generally between 6 and $8 . \mathrm{pH}$ lowers than 4 will produce sour taste and higher value above 8.5 bitter taste. Higher value of $\mathrm{pH}$ hastens the scale formation in water heating apparatus and reduces the germicidal potential of chlorine. $\mathrm{pH}$ below 6.5 starts corrosion in pipes, thereby releasing toxic metals such as zinc, lead, cadium, copper among others.

Mineral determination and hardness of water samples

Hardness of water is caused by the presence of multivalent metallic cations and is largely due to calcium, $\mathrm{Ca}^{2+}$, and magnesium, $\mathrm{Mg}^{2+}$ ions. Hardness is the measure of capacity of water to react with soap, hard water requiring considerably more soap to produce lather. It is not caused by single substance but by a variety of dissolved polyvalent metallic ions, predominantly calcium and magnesium cations. The low and high value of hardness in the water samples has advantages and disadvantages. Absolutely soft water is tasteless. Hard water is useful to growth of children due to presence of calcium. Hardness as shown in Table 3 above are within limits of $100 \mathrm{mg} / \mathrm{l}$ as stipulated by NAFDAC as the maximum amount allowable.

Chloride is one of the major inorganic anion in water. In potable water, the salty taste is produced by the chloride concentrations is variable and dependent on the chemical composition. There is no known evidence that chlorides constitute any human health hazard. For this reason, chlorides are generally limited to $250 \mathrm{mg} / \mathrm{l}$ according to NAFDAC standard in supplies intended for public use.

Magnesium is a common constituent in natural water. Magnesium salts are important contributors to the hardness of water which break down when heated, forming scale in boilers. The magnesium concentration may vary from zero to several hundred milligrams. Chemical softening, reverse osmosis, electrodialysis, or ion exchange reduces the magnesium and associated hardness to acceptable levels.

Copper enters the water system through mineral dissolution, industrial effluents because of its use as algicide and insecticide and through corrosion of copper alloy water distribution pipes. It may occur in simple ionic form or in one of many complexes with groups, such as cyanides, chlorides, ammonia or organic ligands. The tests for copper is essential because of dissolved copper salts even in low concentrations are poisonous to some biota. Desirable limit for copper in potable water as set by NAFDAC is $1.00 \mathrm{mg} / \mathrm{l}$ maximum.

The major physiological effects resulting from the ingestion of large quantities of sulfate are catharsis, dehydration, and gastrointestinal irritation. Water containing magnesium sulfate at levels above $600 \mathrm{mg} / \mathrm{l}$ acts as a purgative in humans. The presence of sulfate in drinking water can also result in a noticeable taste. The lowest taste threshold concentration for sulfate is approximately 200 $\mathrm{mg} / \mathrm{l}$ as set by NAFDAC, as the sodium salt. Sulfate may also contribute to the corrosion of distribution systems.

Nitrates generally occur in trace quantities in surface waters but may attain high levels in some ground waters. Nitrite in water is either due to oxidation of ammonium compounds or due to reduction of nitrate. It can be toxic to certain aquatic organisms even at concentration of $1 \mathrm{mg} / \mathrm{l}$ but the maximum for humans is $50 \mathrm{mg} / \mathrm{l}$ as set by NAFDAC. In 
excessive limits, it contributes to the illness known as methenoglobinaemia in infants.

\section{Carbon dioxide in water samples}

Table 3 shows that all the samples fell within limits as stipulated by NAFDAC to be $50 \mathrm{mg} / \mathrm{l}$ as allowable maximum.

\section{Microbial Assessment of samples Aerobic mesophilic count (Plate count) of samples}

The total plate count values of sachet water, yoghurt and zobo drink samples are shown in Table 4 and 5 below. According to Pelizar et al. (1972), water of good quality is expected to give a low count, less than 100 CFU/ml. Samples TAN A and DEO A had the highest and lowest plate counts of $3.16 \times 10^{2}$ and $1.41 \times 10^{2} \mathrm{CFU} / \mathrm{ml}$ respectively but were still within the limit stipulated by NAFDAC and WHO. All yoghurt samples and zobo drinks also conformed to standards.

High plate counts are indicative of poor, unhygienic handling and processing practices. Bacterial growth in water may be unnoticed even in transparent packaged water and the presence of some of these microorganisms may pose a potential risk to consumers (Obiri-Danso et al., 2003). According to World Health Organization report (2002), a high plate count concentration does not itself present a risk to human health. Nevertheless, Aerobic Mesophilic counts are used as good indicators of the overall quality of production (Ferreira et al., 1994; ObiriDanso et al., 2003). However, in bottled and factory-bagged sachet water, the containers used in packaging are produced in very large quantities, stored over a long period of time and used when needed. Ferreira et al. (1994) and Leclerc (1994) have shown that total plate counts in natural mineral waters are low at around $10 \mathrm{CFU} / \mathrm{ml}$, but Warburton et al. (1992) have demonstrated that the numbers increase after bottling to about $10^{3}-10^{5}$ $\mathrm{CFU} / \mathrm{ml}$ and occasionally to $10^{7}$ within $2-7$ days. Warburton et al. (1992) have also shown that stored, unused bottles can contain bacteria and may be a factor in the overall contamination of the finished product.

Secondly, the length of time and conditions that bottled and factory plasticbagged water remain in distribution before reaching the consumer provides an opportunity for already established bacteria to grow and increase in number.

Thirdly, Hunter and Burge (1987) have shown that charcoal filters used in removing objectionable tastes and odours from drinking water can support large bacterial populations as they concentrate both bacteria and organic nutrients. Bacterial numbers as high as 7.106 $\mathrm{ml}$ were detected in the effluent from a charcoal filter 6 days after installation.

Lastly, polythene bags used in bagging sachet water are imported as hoses that are cut into appropriate sizes and one side heat sealed before being sent to printing houses for labelling, all of which can lead further contamination. There is no evidence that high counts of heterotrophic bacteria have had health effects but total plate counts are good indicators of the overall quality of production (Ferreira et al., 1994).

These may therefore be used in assessing the cleanliness of the different brands of sachet drinking waters, yoghurt and zobo drinks sold in Nsukka metropolis. The low plate count observed in zobo and yoghurt can be attributed to the cell death, injuries and homeostatis disturbance potentiated by the boiling effects, the antimicrobial effects of ginger extract (in zobo), refrigeration effect on the associated microorganisms and the inability of the microorganisms to muzzle up enough energy to overcome the resultant stress (Ogiehor et al., 2008; Rodrigues et al., 2010).

\section{Coliform Bacteria and Escherichia coli Count of samples}

All samples except water sample, ECA A (as shown in Table 6 and 7 below) fell 
within the limit permissible by NAFDAC and WHO for potable water, and yoghurt. This is in line with the work done on water by Enwere and Ade (2006). WHO (2008) water standard stated that all water directly intended for drinking, E. coli and thermotolerant coliform bacteria must not be detectable in any $100 \mathrm{ml}$ of sample.

The absence of faecal indicator bacteria in most brands of sachet drinking water, yoghurt and zobo samples could be attributed to better hygienic practices observed in the producing industry/area. These include improved and hygienic filling system and use of non-returnable plastic containers. However, because coliform bacteria are most commonly associated with sewage or surface waters, the presence of coliform bacteria in drinking water (sample ECA A) indicates that other disease-causing organisms (pathogens) may be present in the water system. The presence of fecal coliform in a drinking water sample often indicates recent fecal contamination meaning that there is a greater risk that pathogens are present.

E. coli is a subgroup of the fecal coliform group. Most E. coli are harmless and are found in great quantities in the intestines of people and warm-blooded animals. The presence of $E$. coli in a drinking water sample almost always indicates recent fecal contamination - meaning that there is a greater risk that pathogens are present (West, 2006).

Also yoghurt and zobo drinks were negative to coliform and $E$. coli and the yoghurt samples conformed to standards set by NAFDAC and WHO (Table above). The heating treatment of zobo (boiling temperature) and milk at $85-90{ }^{\circ} \mathrm{C}$ for $4-20$ seconds to 30 minutes (high pasteurization) usually applied in zobo and yoghurt production is sufficient to kill the majority, if not all, of the autochthonous microorganisms of raw milk and zobo extract (Con et al., 1996; Tamine, 2002; Olson and Aryana, 2007; Ogeihor et al., 2008), including the coliforms.

The presence of faecal indicators, $P$. aeruginosa and Aeromonas in bagged waters has been reported to be due to poor hygienic practices of producers, failure to wash hands, illiteracy and sheep and goats in the vicinity of factories (Coroler et al., 1996). Todar (2008) reported that Pseudomonas spp are tolerant to a wide variety of physical condition such that they are able to grow at temperatures as high as $42{ }^{\circ} \mathrm{C}$ and requires very simple nutrition for growth. This can be used to justify the presence of Pseudomonas spp in some sachet water samples as shown in Table 8 above.

Upon manufacturing, Pseudomonas spp may be present but inactive because the temperature at that time will not support its growth. As most of these samples are kept and hawked directly under the sun, the temperature increases thereby making it favorable for the growth of Pseudomonas spp.

\section{Salmonella spp of samples}

The absence of Salmonella spp suggests that the source of water used in the manufacturing of the sachet water, zobo drink and yoghurt is free form faecal contamination, a good indication of Good Manufacturing Practice (GMP) and good personnel hygiene (El Bakri and El Zubeir, 2009). The primary habitat of Salmonella spp is the intestinal tract of animals such as birds, reptiles, farm animals, humans and occasionally insects. They can also be found in other parts of the body from time to time. As intestinal forms, they are excreted in faeces and may be transmitted by insects and other living creatures. They are also found in polluted water contaminated by insects or by other means. 
Table 1: Samples, locations and capacities.

\begin{tabular}{|c|c|c|}
\hline Sample & Location & Capacity \\
\hline TAN A & Green house 1 & $50 \mathrm{cl}$ \\
\hline TAN B & Green house 2 & $50 \mathrm{cl}$ \\
\hline TAN C & Campus & $50 \mathrm{cl}$ \\
\hline DEO A & Campus & $60 \mathrm{cl}$ \\
\hline DEO B & Beach 1 & $60 \mathrm{cl}$ \\
\hline DEO C & Beach 2 & $60 \mathrm{cl}$ \\
\hline LIO A & Campus & $60 \mathrm{cl}$ \\
\hline LIO B & Odenigwe & $60 \mathrm{cl}$ \\
\hline LIO C & Beach 2 & $60 \mathrm{cl}$ \\
\hline ASH A & Campus & $50 \mathrm{cl}$ \\
\hline ASH B & Onuiyi & $50 \mathrm{cl}$ \\
\hline ASH C & Beach & $50 \mathrm{cl}$ \\
\hline JIV A & Odenigbo & $60 \mathrm{cl}$ \\
\hline JIV B & Beach & $60 \mathrm{cl}$ \\
\hline JIV C & Campus & $60 \mathrm{cl}$ \\
\hline ECA A & Market (Enugu road) & $50 \mathrm{cl}$ \\
\hline ECA B & Odenigbo & $50 \mathrm{cl}$ \\
\hline ECA C & Odenigwe & $50 \mathrm{cl}$ \\
\hline Zobo 1 & Market (Enugu road) & $75 \mathrm{cl}$ \\
\hline Zobo 2 & Odenigbo & $50 \mathrm{cl}$ \\
\hline Zobo 3 & Campus & $75 \mathrm{cl}$ \\
\hline OSA 1 & Campus & $50 \mathrm{cl}$ \\
\hline OSA 2 & Odenigbo & $75 \mathrm{cl}$ \\
\hline SUP 1 & Campus & $50 \mathrm{cl}$ \\
\hline SUP 2 & Odenigbo & $50 \mathrm{cl}$ \\
\hline
\end{tabular}

Table 2: Physical/Organoleptic Examination of sachet water samples.

\begin{tabular}{llllc}
\hline Samples & Colour & Odour & Taste & $\begin{array}{c}\text { Presence of } \\
\text { particles }\end{array}$ \\
\hline TAN A & Colourless & Odourless & Tasteless & Absent \\
TAN B & Colourless & Odourless & Tasteless & Absent \\
TAN C & Colourless & Odourless & Tasteless & Absent \\
DEO A & Colourless & Odourless & Tasteless & Absent \\
DEO B & Colourless & Odourless & Tasteless & Absent \\
DEO C & Colourless & Odourless & Tasteless & Absent \\
LIO A & Colourless & Odourless & Tasteless & Absent \\
LIO B & Colourless & Odourless & Tasteless & Absent \\
LIO C & Colourless & Odourless & Tasteless & Absent \\
ASH A & Colourless & Odourless & Tasteless & Absent \\
ASH B & Colourless & Odourless & Tasteless & Absent \\
ASH C & Colourless & Odourless & Tasteless & Absent \\
\hline
\end{tabular}




\begin{tabular}{lllll}
\hline JIV A & Colourless & Odourless & Tasteless & Absent \\
JIV B & Colourless & Odourless & Tasteless & Absent \\
JIV C & Colourless & Odourless & Tasteless & Absent \\
ECA A & Colourless & Odourless & Tasteless & Absent \\
ECA B & Colourless & Odourless & Tasteless & Absent \\
ECA C & Colourless & Odourless & Tasteless & Absent \\
\hline
\end{tabular}

Table 3: The physical characteristics of the yoghurt and zobo drink samples used in the study.

\begin{tabular}{ccccc}
\hline Samples & Colour & Odour & Taste & $\begin{array}{c}\text { Presence of } \\
\text { particles }\end{array}$ \\
\hline Zobo 1 & Coloured & Unobjectionable & Unobjectionable & None \\
Zobo 2 & Coloured & Unobjectionable & Unobjectionable & Yes \\
Zobo 3 & Coloured & Unobjectionable & Unobjectionable & None \\
OSA 1 & Milky & Unobjectionable & Unobjectionable & None \\
OSA 2 & Milky & Unobjectionable & Unobjectionable & None \\
SUP 1 & Milky & Unobjectionable & Unobjectionable & None \\
SUP 2 & Milky & Unobjectionable & Unobjectionable & None \\
\hline TAN = Tance sachet water; SUP = Super yogo; DEO = De Occasion sachet water; OSA = Osaka yoghurt; \\
LIO = Lion sachet water; ASH = Ashor sachet water; JIV = Jives sachet water; ECA = Ecassion sachet water; \\
Zobo = Zobo drink
\end{tabular}

Table 4: Chemical assessment of sachet water samples.

\begin{tabular}{|c|c|c|c|c|c|c|}
\hline $\begin{array}{l}\text { Samples/ } \\
\text { parameters }\end{array}$ & Ashor & DeOccasion & Tance & Lion & Jives & Ecassion \\
\hline TDS & 4.63 & 2.66 & 3.08 & 6.64 & 15.03 & 8.56 \\
\hline COND & $7.90 \times 10^{0}$ & $4.31 \times 10^{0}$ & $5.23 \times 10^{0}$ & $1.1 \times 10^{1}$ & $6.54 \times 10^{1}$ & $8.93 \times 10^{0}$ \\
\hline $\mathrm{CO}_{2}$ & 5.00 & 4.00 & 4.00 & 8.00 & 5.00 & 6.00 \\
\hline $\mathrm{Cl}$ & 12.00 & 13.00 & 12.00 & 9.00 & 12.00 & 11.00 \\
\hline $\mathrm{pH}$ & $7 . .35$ & 7.50 & 7.35 & 7.36 & 7.42 & 7.35 \\
\hline $\mathrm{Cu}$ & 0.18 & 0.01 & 0.88 & 0.04 & 0.43 & 0.63 \\
\hline HD & 0.24 & 8.00 & 6.00 & 15.00 & 10.00 & 13.00 \\
\hline ALK & 12.00 & 12.00 & 26.00 & 28.00 & 16.00 & 18.00 \\
\hline SUL & 3.00 & 2.00 & 2.00 & 3.00 & 2.00 & 3.00 \\
\hline $\mathrm{NO}_{3}$ & ND & ND & ND & ND & ND & ND \\
\hline $\mathrm{NO}_{2}$ & ND & ND & ND & ND & ND & ND \\
\hline MOA & 10.00 & 11.00 & 16.00 & 14.00 & 16.00 & 12.00 \\
\hline Phe & ND & ND & ND & ND & ND & ND \\
\hline $\mathrm{Ca}$ & 0.16 & 5.30 & 4.00 & 10.00 & 10.67 & 8.95 \\
\hline $\mathrm{Mg}$ & 0.08 & 2.60 & 2.00 & 5.00 & 5.33 & 4.63 \\
\hline $\mathrm{Fe}$ & ND & ND & ND & ND & ND & ND \\
\hline
\end{tabular}


Table 5: Aerobic Mesophilic Count of Sachet Water Samples.

\begin{tabular}{lcc}
\hline & PCA & Mean Total \\
\hline TAN A & 320,312 & $3.16 \times 10^{2}$ \\
TAN B & 200,197 & $1.97 \times 10^{2}$ \\
TAN C & 210,200 & $2.05 \times 10^{2}$ \\
DEO A & 143,138 & $1.41 \times 10^{2}$ \\
DEO B & 257,261 & $3.59 \times 10^{2}$ \\
DEO C & 130,127 & $2.57 \times 10^{2}$ \\
LIO A & 178,183 & $1.81 \times 10^{2}$ \\
LIO B & 283,280 & $2.82 \times 10^{2}$ \\
LIO C & 165,161 & $1.63 \times 10^{2}$ \\
ASH A & 211,217 & $2.14 \times 10^{2}$ \\
ASH B & 201,205 & $2.03 \times 10^{2}$ \\
ASH C & 265,261 & $2.63 \times 10^{2}$ \\
JIV A & 317,320 & $3.19 \times 10^{2}$ \\
JIV B & 288,280 & $2.90 \times 10^{2}$ \\
JIV C & 285,280 & $2.83 \times 10^{2}$ \\
ECA A & 300,303 & $3.02 \times 10^{2}$ \\
ECA B & 200,205 & $2.03 \times 10^{2}$ \\
ECA C & 180,184 & $1.82 \times 10^{2}$ \\
\hline
\end{tabular}

Table 6: Aerobic Mesophilic Count of Yoghurt and Zobo drinks.

\begin{tabular}{lcc}
\hline Sample & PCA & Mean total \\
\hline ZOBO 1 & 100,98 & $9.9 \times 10^{1}$ \\
ZOBO 2 & 140,138 & $1.39 \times 10^{2}$ \\
ZOBO 3 & 140,150 & $1.48 \times 10^{2}$ \\
OSA 1 & 98,100 & $9.9 \times 10^{1}$ \\
OSA 2 & 157,161 & $1.59 \times 10^{2}$ \\
SUP 1 & 100,101 & $1.01 \times 10^{2}$ \\
SUP 2 & 150,147 & $1.49 \times 10^{2}$ \\
\hline
\end{tabular}

TAN $=$ Tance sachet water; SUP $=$ Super yogo; DEO $=$ De Occasion sachet water; OSA $=$ Osaka yoghurt Zobo $=$ Zobo drink; $\mathrm{LIO}=$ Lion sachet water; ASH $=$ Ashor sachet water; JIV = Jives sachet water; ECA = Ecassion sachet water.

\section{Conclusion}

Based on the bacteriological quality of assessed water, yoghurt and zobo samples, the study has attempted to examine the public health implication of packaged water products, yoghurt and zobo drinks in Nsukka metropolis. Most packaged water apparently were of good quality but some are contaminated. It should, however, not be automatically assumed that packaged water in sachets is generally safe. Although the technologies used in this water industry present barriers that prevent pathogen presence in the final product, the quality of the packaged water was compromised significantly as it moved from the manufacturer to the consumer. Regulatory activities that promote core hygiene values (for instance, hand washing, general cleanliness of storage environment, vendors' personal hygiene and vending containers) and a proper handling culture could produce the 
Table 7: Coliform Bacteria and Escherichia coli in water samples.

\begin{tabular}{lcc}
\hline Sample & Coliform & $\boldsymbol{E . c o l i}$ \\
\hline TAN A & 0 & 0,0 \\
TAN B & 0 & 0,0 \\
TAN C & 0 & 0,0 \\
DEO A & 0 & 0,0 \\
DEO B & 0 & 0,0 \\
DEO C & 0 & 0,0 \\
LIO A & 0 & 0,0 \\
LIO B & 0 & 0,0 \\
LIO C & 0 & 0,0 \\
ASH A & 0 & 0,0 \\
ASH B & 0 & 0,0 \\
ASH C & 0 & 0,0 \\
JIV A & 0 & 0,0 \\
JIV B & 0 & 0,0 \\
JIV C & 0 & 0,0 \\
ECA A & 210 & 27 \\
ECA B & 0 & 0,0 \\
ECA C & 0 & 0,0 \\
& & \\
\hline
\end{tabular}

Table8: Coliform Bacteria and Escherichia coli in Yoghurt and Zobo drink Samples.

\begin{tabular}{lccccccc}
\hline $\begin{array}{l}\text { Samples } \\
\text { /Parameters }\end{array}$ & ZOBO1 & ZOBO 2 & ZOBO 3 & OSA 1 & OSA 2 & SUP 1 & SUP 2 \\
\hline Coliform & 0 & 0 & 0 & 0 & 0 & 0 & 0 \\
E. coli. & 0,0 & 0,0 & 0,0 & 0,0 & 0,0 & 0,0 & 0,0 \\
\hline
\end{tabular}

TAN = Tance sachet water; SUP = Super yogo ; DEO = De Occasion sachet water; OSA = Osaka yoghurt; Zobo = Zobo drink; $\mathrm{LIO}=$ Lion sachet water; ASH = Ashor sachet water; JIV = Jives sachet water; ECA = Ecassion sachet water.

desired improvements rather than a tenacious focus on end-product monitoring, which does not always give a complete picture in terms of microbiological risk assessment.

Also, an extreme shift towards implementation of the proposed ban on water in sachets may not be socially desirable. Thus, while seeking to protect public health in the developing world, there is need for regulatory and health agencies to maintain a balanced position that concurrently improves social welfare and access to drinking water. Obviously, in concert with international agencies such as the World Health Organization, this would involve considerable support for locally sourced initiatives such as the nation's packaged water, which apparently covers for institutional inadequacies in public water supply in Nigeria and other parts of the developing world. 
Table 9: Pseudomonas spp in water samples.

\begin{tabular}{lc}
\hline Sample & Parameter \\
\hline TAN A & Negative \\
TAN B & Positive \\
TAN C & Negative \\
DEO A & Negative \\
DEO B & Negative \\
DEO C & Negative \\
LIO A & Negative \\
LIO B & Negative \\
LIO C & Positive \\
ASH A & Positive \\
ASH B & Negative \\
ASH C & Negative \\
JIV A & Negative \\
JIV B & Negative \\
JIV C & Negative \\
ECA A & Positive \\
ECA B & Negative \\
ECA C & Negative \\
\hline TAN = Tance sachet water ; ASH = Ashor sachet water; DEO = De Occasion sachet water; JIV = Jives \\
sachet water; LIO = Lion sachet water; ECA = Ecassion sachet water
\end{tabular}

The total content of the microorganism in the yoghurt and zobo drink was not high enough to cause health hazard to the consumers. However, to maintain and enhance their bacteriological properties, producers and hawkers of yoghurt and zobo drink should maintain good hygiene during preparation and sales of the products respectively to avoid the possible danger of contamination or recontamination of the products. Adequate pasteurization of these products remains a very effect way of improving and assuring wholesomeness.

It is recommended that standards should be set for zobo drinks as this beverage is now virtually consumed by all and sundry and in addition, the reviewing of standards for pure water and street vended yoghurt business by NAFDAC to ensure that producers comply with the standards set at every stage of the production and distribution processes. All though the task of effectively regulating the myriads of these products in the nation, given the expanse of the land, inadequate staff capabilities amongst others, there still remains a big challenge to NAFDAC. Opportunities exist for improvements in the current regulatory scheme, institutional capacity and collaborative partnership that could make efficient the regulation of the packaged water and street vended yoghurt industry (as well as zobo drink) and ultimately, better the lot of the consuming public.

\section{ACKNOWLEDGEMENTS}

We thank the Microbiological analyst, National Agency for Food and Drug Administration and Control (NAFDAC), PortHarcourt, who assisted in the analysis of the samples.

\section{REFERENCES}

Ajayi S. 2005. Regulatory Standards of Water and Other Beverages. Food forum. A publication of the Nigerian Institute of Food Science and Technology: Lagos.

Aliyu L. 2000. Roselle (Hibiscus sabdariffa L.) Production as affected by pruning and sowing date. J. Appl, Agric, Technol. 6: 16-20

Anne CB. 2002. Chemical and Microbiological quality of sachet water. 
www.fda.gov/fdac/features/402/h20.html. 20k.

APHA. 1992. Standard Methods for the Examination of Water and Waste Water $\left(18^{\text {th }}\right.$ edn), American Public Health Association: Washington D.C.

Awolola GV, Dosumu OO, Okunla MO, Oluwaniyi OO. 2009. Stability studies and mineral concentrations of some Nigerian packaged fruit juices, concentrates and local beverages. Afr. J, Food Sci., 3(3): 82-85.

Brennam GJ, Butters RJ, Cowell DN, Lilly VEA. 1976. Food Engineering Operations ( $2^{\text {nd }}$ edn). Applied Sciences Publishers Limited: London.

Campbell NA, Heyden BJ, William B. 2006. Biology: Exploring Life. Person Prentice Hall: Boston, Massachusetts.

Çon AH, Çakmakçi A, Ça lar A, Gökalp HY. 1996. Effects of different fruits and storage periods on microbiological qualities of fruit-flavored yogurt produced in Turkey. J. Food Prot., 59: 402-406.

Coker OO. 2004. Reforming The Water Sector In Lagos State: The Lagos Model City Development Strategies: From Vision to Growth and Poverty Reduction 24-26 November 2004 Hanoi, Vietnam

Coroler L, Elomari M, Hoste B, Gillis M, Izard D, Leclerc H. 1996. Pseudomonas rhodesiae sp. nov., a new species isolated from natural mineral waters. Syst, Appl. Microbiol., 19: 600-607.

Dada, A. C. 2009a. Sachet water phenomenon in Nigeria Assessment of the potential health impacts. Afr. J. Micro. Res., 3(1): $15-21$.

Dada AC. 2009b. Towards a successful packaged regulation in Nigeria. Sci. Res. Essay, 49: 921-928.

Dibua UE, Esimone CO, Ndianefo PC. 2007. Microbiological and physiochemical characterization of sachet water samples marketed in Nsukka campus of the University of Nigeria. Biores., 5(1): 189193.

Egwari L. Aboaba O. 2002. Environmental impact on the bacteriological quality of domestic water supplies in Lagos Nigeria.
Revised Saude Publication, 36(4): 513520.

El Bakri JM, El Zubeir IEM. 2009. Chemical and microbiological evaluation of plain and fruit yoghurt in Khartoum State. Sudan Intern. J. Dairy Sci., 4: 1-7.

Enwere NJ, Ade AI. 2006. Comparison of the microbial, chemical and physical characteristics of some sachet water, bottled water and public water sold in Makurdi Town, Benue State, Nigeria. A paper presented at the Annual National Conference of the Home Economics Research Association of Nigeria (HERAN) held at the Princess Alexandra Unity Hall, University of Nigeria, Nsukka from September $6^{\text {th }}$ to $9^{\text {th }}, 2006$.

Fasoyiro SB, Ashaye OA, Adeola A, Samuel FO. 2005. Chemical and Storability of Fruit-Flavoured (Hibiscus sabdariffa) Drinks. World J. Agric. Sci., 1(2): 165168.

Ferreria AC, Morais PV, Gomes C, Da Costa, MS. 1994. Alterations in total bacteria, iodonitrophenyltetrazolium (INT) positive bacteria and heterotrophic plate counts of bottled mineral water. Canadian J. Micro., 40: $72-77$.

Hunter PR, Burge SH. 1987 The bacteriological quality of natural mineral waters. Epidemio. Infect., 99: 439-443.

Kassenga GR. 2007. The health-related microbiological quality of bottled drinking water sold in Dares Salam Tanzania. J. Water Health, 5(1): 179-185.

Kolars JC, Levitt MD, Mustapha Aouji DAG, Savaino DA. 1984. An autodigesting source of lactose. The New England J. Med., 130: 1-3

Leclerc H. 1994. Les eaux minerales naturelles: flore bacterie'nne native, nature et signification. Eaux Minérales.

Morgan P. 1990. Rural Water Supplies and Sanitation: a Test from Zimbabwe's Plain Research Laboratory. Macmillan Press: London; 284-286.

National Yogurt Association. 2007. Live and active culture yogurt seal program. www.aboutyogurt.com.

Nwafor OE, Ikenebomeh MJ. 2009. Effects of packaging materials on the microbiological, physio-chemical and 
organoleptic quality of zobo drink storage at room temperature. Afr. J. Biotech., 8(12): 2848-2852.

Obiri-Danso K, Okore-Hanson A, Jones K. 2003. The microbiological quality of drinking water sold on the streets in Kumasi, Ghana. Letters in Appl. Micro. 37: 334-339.

Ogan MT. 1992. Microbiological quality of bottled water sold in retail outlets of Nigeria. J. Appl. Bacteriol., 73: 195-181.

Ogiehor IS, Nwafor OE, Owhe-Ureghe UB. 2008 Changes in the quality of zobo beverages produced from Hibiscus sabdarifa (Linn roselle) and the effects of extract of ginger alone or in combination with refrigeration. Afr J. Biotech., 7(8): 1176-1180.

Okpalugo J, Ibrahim K, Izebe KS, Inyang, US. 2008. Aspects of microbial quality of some milk products in Abuja, Nigeria. Trop. J. Pharmaceu. Res., 7(4): 11691177.

Okwu DE, Emenike IN. 2006. Evaluation of the phytonutrients and vitamin content of citius fruits. Intern. J. Mol. Med. Adv. Sci., 2: 1-6.

Olowo SJ. 2005. Standard Operating Procedure for Water Pollution. Nigeria Institute of Food Sciences and Technology: Lagos.

Olson DW, Aryana KJ. 2008. An excessively high Lactobacillus acidophilus inoculation level in yogurt lowers product quality duringstorage. LWT - Food Sci. Tech., 41: 911-918.

Oyebode O. 2005. Water Pollution and Sanitation. A publication of Nigerian Institute of Food Science and Technology: Lagos.

Pelezar JR, Chan FCJ. Krieg RN. 1986. Microbiology ( $5^{\text {th }}$ edn). McGraw-Hill book company, New York; 593-616.

Qi Y, Chin KL, Malekian F, Berhame M, Gager J. 2005. Biological characteristics, nutritional and medicinal value of roselle Hibiscus sabdariffa. Circular- Urban Forestry Natural Resources and Environment, 604: 1-2.
Rodrigues LA, Ortolani MBT, Nero LA. 2010. Microbiological quality of yoghurt commercialized in Viçosa, Minas Gerais, Brazil. Afr. J. Micro. Res., 4(3): 210-213.

Salinas RJ. 1986. Hygiene quality of commercial yoghurts. Alimentaria, 178: 27-30.

Tamine, A. Y. 2002). Fermented milks: a historical food with modern applications a review. European Journal of Clinical Nutrition, 56: 01-15.

Todar K. 2008. Bacteriology. www.textbookofbacteriology.net US Centers for Disease Control and Prevention. 2006. Water borne diseases. Cited online:www.uscentersfordisease controlandprevention .com

Warbuton DW, Austin DW. 1997. Bottled water. In Microbiology of Foods. Chapman and Hall Press: London; 694 895.

Warburton DW, Dodds KL, Burke R, Johnston MA. Laffay PS. 1992. A review of the microbiological quality of bottled water sold in Canada between 1981 and 1989. Canadian J. Micro., 38: 12-19.

West L. 2006. World Water Day: A billion people worldwide lack safe drinking water. Wikipedia free encyclopedia. en.wikipedia.org/wiki/water_crisis.

Wenkam A. 1990. Utilization and processing of fruits: Macmillan Press; London.

WHO 2008. Burden of disease and costeffective estimates, Wikipedia free encyclopedia. http://www.who.int/water_ sanitation_health/disease/wsho302/en/

World Health Organization, WHO 2006. WHO Guidelines for Drinking Water Quality $\left(1^{\text {st }}\right.$ addendum to $3^{\text {rd }}$ edition vol 1). World Health Organization: Geneva; 132.

World Health Organization 2002. Heterotrophic Plate Count Measurement in Drinking Water Safety Management. WHO Public Health Expert Report: Geneva, Switzerland.

Younus S, Masud T, Aziz T. 2002. Quality evaluation of market yoghurt/dahi. Pakis. J. Nutr. 1(5): 226-230. 